\title{
Ketoprak, Seni Pertunjukan Tradisional Jawa di Sumatera Utara: Pengembangan dan Keberlanjutannya
}

\author{
Torang Naiborhu, Nina Karina \\ Fakultas Ilmu Budaya, \\ Universitas Sumatera Utara \\ Jalan Universitas No. 19 Medan \\ Email: torang.naiborhu@yahoo.co.id
}

\begin{abstract}
Ketoprak (Ketoprak Dor) is a Javanese art performance found in North Sumatera which was originated from Surakarta, Central Java. The performance combines dialogue, drama, dance, and music. It is performed on stage, taking stories about history, old kingdom, fairy tale, daily life, and others with an interspersed joke. Data collection is collected through observation and interviews with the ketoprak artists, owners of the studio, and the spectators, and a documentation study. The data is analyzed by qualitative analysis technique using performing art theory, ethnomusicology, and history. The results are, first, ketoprak in North Sumatera began to be slowly abandoned despite the adoption of local culture in music, story, clothing, as well as vocabularies used. Second, for its development, it requires strategies for the survival of the performing art among its audiences, particularly Javanese community.
\end{abstract}

Keywords: Ketoprak Dor, ketoprak in North Sumatra, developing ketoprak, art performance

\begin{abstract}
ABSTRAK
Ketoprak (Ketoprak Dor) adalah seni pertunjukan Jawa di Sumatera Utara yang berasal dari Surakarta, Jawa Tengah. Pementasannya menggunakan dialog, drama, tarian, dan musik. Ketoprak dipertunjukkan di atas panggung dengan mengambil cerita sejarah, kerajaan, dongeng, kehidupan sehari-hari, dan lainnya dengan diselingi lawak. Pengumpulan data dilakukan melalui pengamatan dan wawancara kepada seniman ketoprak, pemilik sanggar, dan masyarakat pengguna, serta studi dokumentasi, dan hasilnya dianalisis dengan teknik analisis kualitatif menggunakan teori seni pertunjukan, etnomusikologi, dan metode sejarah. Hasil yang diperoleh menunjukkan bahwa ketoprak di Sumatera Utara secara perlahan mulai ditinggalkan walaupun telah mengadopsi budaya setempat dalam hal musik, cerita, busana, atau tata bahasa yang dipakai. Untuk pengembangannya diperlukan upaya-upaya strategis agar seni pertunjukan ini dapat bertahan dan tetap diminati oleh masyarakat, khususnya komunitas Jawa.
\end{abstract}

Kata kunci: Ketoprak Dor, ketoprak di Sumatra Utara, pengembangan ketoprak, seni pertunjukan 


\section{PENDAHULUAN}

Penelitian tentang ketoprak (Ketoprak Dor) di Sumatera Utara, khususnya di Tanah Deli telah dilakukan oleh Tutiek Sugiarti (1989), Panji Suroso (2012), dan Selamat Hariadi (2015). Penelitian Sugiarti yang dituangkan dalam skripsi berjudul Ketoprak Dor: Perkembangan, Fungsi, dan Tantangannya di Sumatera Utara (1920-1985) mengkaji asal-usul ketoprak di Sumatera Utara, pengaruh Melayu pada ketoprak, fungsinya, dan tantangan terhadap perkembangan masa kini dan mendatang.

Dijelaskan oleh Sugiarti (1989: 28-30) bahwa panen perdana tembakau di tanah Deli pada tahun 1865 membawa sukses dan menjadi perbincangan di Eropa karena kualitasnya yang sangat baik. Ned Handel Mij, sebuah bank Belanda, kemudian mendirikan perseroan terbatas yang diberi nama Deli Maatschappij di tanah Deli. Beberapa maskapai lain pun segera membuka perkebunan baru di daerah ini. Michael van Langenberg (1976: 95) mengatakan bahwa sukses panen perdana tersebut segera mengubah daerah ini menjadi het dollar landsch dengan mendirikan 17 perkebunan tembakau pada tahun 1863 , dan meningkat menjadi 76 pada tahun 1884 .

Meningkatnya jumlah perkebunan tersebut diikuti pula dengan lonjakan produksi yang didukung oleh tenaga kerja (buruh dan kuli) yang memadai. Buruh yang didatangkan untuk memenuhi kebutuhan tersebut salah satunya ialah orang-orang Jawa. Jumlahnya pada tahun 1884, sekitar 1.771 kuli, tahun 1900 mencapai 25.224 jiwa, dan meningkat terus pada tahun-tahun berikutnya (Reid, 1987: 85). Pada tahun 1929, kuli Jawa di perkebunan Sumatera Timur telah mencapai 239.281 jiwa, dan pada tahun 1930 total penduduk Jawa di daerah ini telah mencapai 589.836 jiwa atau $35 \%$ dari total penduduk Sumatera Timur (Naiborhu, 2016: 22). Pada saat ini, masyarakat Jawa telah tersebar di Suma- tera Utara dengan berbagai kesenian yang mereka bawa dari daerah asalnya, seperti wayang kulit, kuda kepang, ludruk, reog, dan ketoprak (Heristina Dewi, 2016: 140).

Munculnya grup-grup ketoprak di perkebunan Sumatera Timur diperkirakan sekitar tahun 1920-an, dan sejak saat itulah, kesenian ini diwariskan dari generasi ke generasi dengan beberapa perubahan sesuai dengan perkembangan budaya. Pihak kolonial juga mengizinkan keberadaan berbagai jenis hiburan tersebut agar para buruh tetap betah, lalu dengan demikian tenaganya dapat dimanfaatkan secara terus-menerus (Sugiarti, 1989: 35; Said, 1990: 27, 90, 93, 100). ${ }^{1}$

Panji Suroso, dalam bukunya yang berjudul Ketoprak Dor di Helvetia (2012) mengkaji tentang fenomena percampuran budaya pada pertunjukan Ketoprak Dor di Kelurahan Helvetia Medan. Dikatakan bahwa pertunjukan Ketoprak Dor tidak berdasar kepada naskah tertulis, tetapi lebih kepada ingatan saja. Oleh sebab itu, improvisasi dalam pertunjukan menjadi hal yang sangat lumrah. Dialog maupun monolog menggunakan bahasa Jawa campuran, dan bahasa Jawa ngoko. Karakter tokoh yang diperankan diekspresikan dengan dukungan gerak tari dan musik yang sudah bercampur dengan budaya setempat (2012: 65-66). Penyebab lainnya, yaitu faktor sejarah, transmisi, kreativitas yang tercipta, interaksi budaya, perkembangan zaman, dan teknologi (2012: 103).

Penelitian Selamat Hariadi (2015) dalam skripsi yang berjudul Studi DeskriptifKetoprak Dor pada Upacara Adat Perkawinan Jawa di Kelurahan Jati Makmur, Kecamatan Binjai Utara, Kota Binjai menyoroti tentang deskripsi penyajian, dan fungsi pertunjukan Ketoprak Dor pada upacara adat perkawinan Jawa di Kota Binjai, Sumatera Utara. Dijelaskan bahwa penyajian ketoprak pada upacara ini, yaitu pada malam hari pukul 21.00 WIB hingga dini hari, pukul 04.00 WIB. Fungsi utamanya adalah sebagai tontonan dan 
sarana penyampai pesan berisi tuntunan hidup bagi mempelai dan penonton yang menyaksikannya.

\section{METODE}

Data yang diperoleh dalam tulisan ini berasal dari dua sumber, yaitu data primer dan sekunder. Data primer diperoleh melalui wawancara mendalam (in-depth interview) dan pengamatan berperan serta (participant observation) yang diikuti dengan diskusi kelompok terfokus (focus group discussion). Kelengkapan untuk memperoleh data tersebut menggunakan kamera video, foto, dan tape recorder.

Seleksi informan didasarkan pada pengelompokan informan kunci yang mencakup: pemilik grup kesenian untuk mendapatkan data tentang eksistensi dan manajemen grup ketoprak; para pemain ketoprak untuk mendapatkan informasi perihal lakon, perannya sebagai aktor dan aktris; penanggap untuk mendapatkan alasan dan latar belakang mengundang ketoprak; dan penonton untuk mendapatkan informasi kesan-kesan dan harapan yang diinginkan dari pertunjukan ketoprak. Jumlah informan tidak dibatasi sepanjang data yang dibutuhkan masih diperlukan.

Data sekunder diperoleh melalui bukubuku, dokumen, kegiatan-kegiatan organisasi, catatan-catatan administrasi organisasi, dan sebagainya. Kedua jenis data tersebut kemudian dianalisis melalui teknik analisis kualitatif dengan menggunakan teori seni pertunjukan, etnomusikologi, dan metode sejarah. Teori seni pertunjukan dari Milton Singer (dalam Murgianto, 2003) dipakai untuk mengkaji aspek pertunjukan, meliputi: waktu yang terbatas, awal dan akhir, terorganisir, adanya pemain, penonton, tempat, dan kesempatan untuk mempertunjukkannya. Sementara itu, teori etnomusikologi Alan P. Merriam (1964: 172) dipakai untuk mengkaji faktor-faktor penyebab perubahan kesenian. Dikatakan bahwa perubahan dalam kesenian dapat berasal dari dalam lingkungan kebudayaan atau internal, dan juga dapat berasal dari luar kebudayaan atau eksternal. Perubahan secara internal dilakukan oleh pelaku-pelaku kebudayaan itu sendiri, sedangkan perubahan eksternal merupakan perubahan yang timbul akibat pengaruh dari luar lingkup kebudayaan tersebut.

Metode sejarah yang digunakan, yaitu heuristik, kritik, interpretasi, dan historiografi. Penelitian diawali dengan mengumpulkan berbagai sumber data terkait dengan masalah yang diteliti, yaitu sumber tertulis untuk tujuan merekonstruksi masa lalu (Kartodirdjo, 1982).

\section{HASIL DAN PEMBAHASAN}

\section{Seni Pertunjukan Ketoprak di Sumatera Utara}

Salah satu kesenian Jawa yang masih bertahan di luar wilayah asalnya adalah ketoprak, yaitu seni teater yang menggunakan dialog, drama, tarian, dan musik. Ketoprak digelar di sebuah panggung dengan mengambil cerita sejarah, kerajaan, dongeng, kehidupan sehari-hari, dan lainnya dengan diselingi lawak (Subanar, 2006).

Sejak kedatangannya hingga tahun 1980an di Sumatera Utara, khususnya Sumatera Timur, pertunjukan ketoprak sudah mengadopsi kisah-kisah masyarakat dan cerita-cerita setempat, khususnya Melayu. Besarnya pengaruh Melayu terlihat pada hampir seluruh pertunjukan, baik tata rias, kostum, nyanyian, tarian, musik, maupun cerita. Patut diduga, pengaruh ini terjadi karena populernya kesenian Melayu pada saat itu melalui onderneming-onderneming yang tumbuh dengan pesat. Bersamaan dengan itu, masa keemasan kesenian Melayu juga berkembang dengan pesat, seperti pertunjukan makyong, teater bangsawan atau pun lagu-lagu Melayu.

Saat ini, pengaruh lainnya tampak pada kostum, tari-tarian, musik, dan tembang (nyanyian) yang digunakan. Tembang Jawa 
yang masih dinyanyikan antara lain Sampak Kinanti, Pangkur, Mares, Sinom, dan Anjasmoro, sedangkan lagu Melayu dan lagu daerah lainnya yang sering dipakai, yaitu Patam-patam, Injit-injit Semut (lagu Melayu), Indung-indung (Pop Nasyida Ria), Mbiring Manggis (lagu Karo), Raja Doli (lagu Batak), Gelang Sipatu Gelang, dan Kapan-kapan (Pop Indonesia).

Cerita setempat yang diangkat antara lain adalah 1001 malam (Stambul Jawi, Istambul, atau Mesiran) dari Baghdad, Hang Tuah, Asal Mula Sialang Buah, dan Legenda Putri Hijau. Cerita Jawa yang sering ditampilkan, seperti Ratapan Anak Tiri, Air Mata Ibu, Kecubung Putih, Sri Dewa-Sri Batara-Sri Wati, dan lain-lain (Sugiarti, 1989: 35).

Umumnya, pementasan ketoprak terdiri atas lima babak: (1) Babak I (pertama), diisi dengan perkenalan tempat, tokoh, kerajaan, dan permulaan konflik; (2) Babak II (kedua), yaitu terjadinya konflik antara kebaikan dengan kejahatan. Babak ini juga diisi dengan lawak dan banyolan oleh $b a$ tur (pembantu tokoh); (3) Babak III (ketiga) adalah penyelesaian konflik, musnahnya angkara murka; (4) Babak IV (keempat), situasi yang ada setelah konflik; dan (5) Babak V (kelima), penutup.

Babak tersebut tidak selalu kaku dan baku sifatnya, namun disesuaikan dengan cerita dan pesanan penyelenggara, serta keberadaan penonton, namun tidak lebih dari lima babak. Setiap babak dapat berlangsung singkat, dapat juga panjang dan lama. Jika penonton banyak dan betah, pertunjukan bisa selesai sampai pukul 04.00 WIB pagi. Namun, jika penonton pulang lebih cepat, pertunjukan juga bisa diselesaikan lebih cepat. Strategi yang dilakukan untuk memperpanjang durasi adalah dengan menampilkan improvisasi melalui tembang-tembang yang disajikan dan selingan lawak (Sugiarti, 1989; Hariadi, 2015).

\section{Pelaku dan Pendukung Pertunjukan}

Para pelaku dan pendukung pertunjukan ketoprak adalah orang yang berperan mewakili setiap tokoh yang diperankannya dan yang terlibat untuk kelancaran sebuah pertunjukan, yaitu pemeran cerita (aktor, aktris), pemusik, penarik layar, dan penonton. Semua unsur ini bersinergi satu dan lainnya untuk mensukseskan jalannya pertunjukan. Pemeran dan pemusik saling mendukung untuk membangun suasana pertunjukan agar tetap hidup sesuai konteksnya. Demikian pula, penonton memberi dukungan agar pelaku pertunjukan tetap bersemangat. Pada saat-saat tertentu, penonton juga memberi respon pada dialog dan adegan yang sedang berlangsung melalui teriakan, atau suitan sehingga antara pelaku (tokoh) pertunjukan dan penonton terjadi komunikasi yang saling menopang satu sama lain.

\section{Pemeran Cerita}

Pemeran cerita (pemain, aktor, aktris) dalam sebuah pementasan ketoprak dibutuhkan sebanyak tujuh sampai dua puluh orang atau lebih sesuai tema cerita yang dibawakan. Setiap pemain memerankan tokoh-tokoh berdasarkan arahan sutradara. Mereka memerankan tokoh raja, patih, punggawa kerajaan, permaisuri, anak, dan lain-lain. Apabila dalam satu pertunjukan kekurangan pemain untuk memerankan seorang tokoh tertentu, maka salah seorang pemain dapat memerankan dua atau lebih tokoh dalam waktu yang berbeda (peran ganda). Syarat utamanya harus bisa menari, menyanyi, atau menembangkan lagu-lagu Jawa ataupun lagu-lagu lainnya, mampu melakukan dialog dengan baik dan menghayati setiap peran yang dimainkannya.

Kadangkala dalam satu pertunjukan pemain yang mendapatkan peran seorang raja akan banyak melakukan dialog dan beberapa kali menembang, tetapi tidak banyak melakukan gerakan tari. Apabila di 


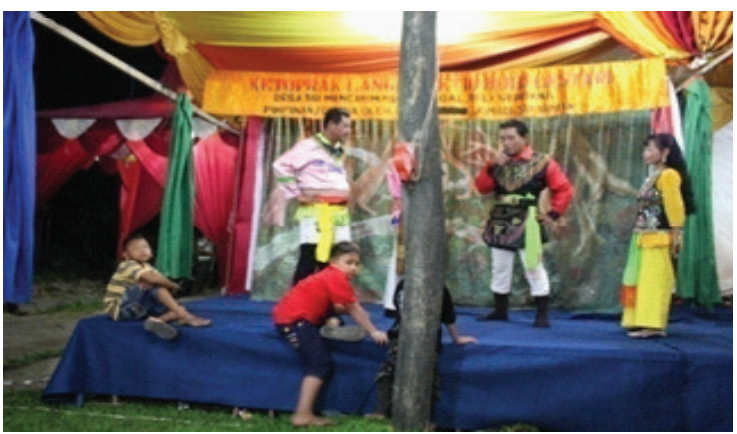

Gambar 1. Kadang-kadang penonton (terutama anak-anak) naik juga ke atas panggung

(Foto: dokumentasi penulis, 2016)

lain pertunjukan orang tersebut mendapatkan peran lain sebagai bintang (lakon), maka pemeran tersebut akan melakukan gerakan tari, dialog, menembang, dan juga gerakan perkelahian atau peperangan.

\section{Pemusik}

Dalam setiap pertunjukan, jumlah pemusik terdiri atas minimal empat orang, yaitu satu orang pemain keyboard atau harmonium, satu orang pemain kendhang, satu orang pemain gendang jidor dan kentrung atau keprak, dan satu orang pemain drum. Di antara pemusik tersebut bisa saja merangkap sebagai aktor untuk bermain musik di saat sudah tidak ada tokoh yang diperankannya, terutama apabila salah seorang pemusik beristirahat karena lelah. Hal ini terjadi karena dalam satu pertunjukan ketoprak hanya pemusiklah yang sangat sedikit memiliki waktu luang untuk beristirahat. Hampir sepanjang pertunjukan, musik dimainkan terus menerus, sedangkan peran dalam cerita dilakukan secara bergantian dan otomatis pemerannya memiliki waktu yang cukup untuk beristirahat sampai giliran penampilannya tiba.

\section{Penarik Layar}

Penarik layar (tukang keterem) ialah orang yang bertugas membuka dan menutup layar pertunjukan pada setiap pergantian babak. Seorang tukang keterem harus mengikuti jalannya cerita sehingga pada

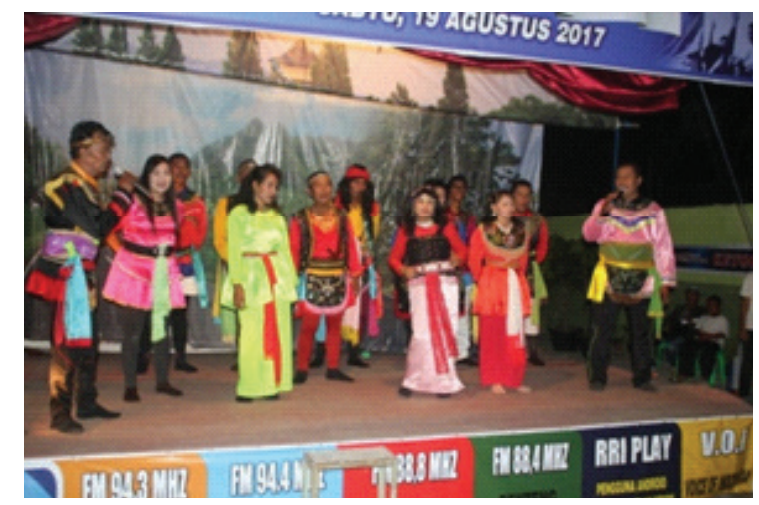

Gambar 2. Kostum Pemain Ketoprak di Sumatera Utara

(Foto: dokumentasi penulis, 2016)

saat pergantian babak, petugas ini dapat menutup dan membuka layar sesuai dengan waktu dan kebutuhannya.

\section{Penonton}

Sebagai sebuah pertunjukan yang berlangsung di atas panggung terbuka, penonton memiliki kebebasan untuk menyaksikan pertunjukan sesuai keinginan masing-masing, bahkan penonton dapat berpindah-pindah tempat sepanjang pertunjukan berlangsung. Kadang-kadang ada yang pergi ke belakang panggung, menyapa dan berbincang dengan pemain, berjalan-jalan, dan berlalu lalang di depan panggung, duduk merapat ke atas panggung atau pun bercengkerama sesama penonton tanpa sepenuhnya mengikuti jalannya pertunjukan (lihat gambar 1).

Karakter para penonton berbeda-beda satu dan lainnya. Penonton anak-anak lebih menyukai adegan lucu, dagelan atau lawak, sedangkan para remaja dan dewasa lebih menyukai adegan percintaan atau hubungan asmara yang secara umum selalu hadir dalam setiap pertunjukan ketoprak, sedangkan para orang tua terutama lanjut usia yang faham dengan jalan cerita, biasanya akan bertahan menyaksikan pertunjukan hingga selesai.

\section{Tata Busana}

Tata busana atau kostum yang dipakai para pemain ketoprak beraneka macam 


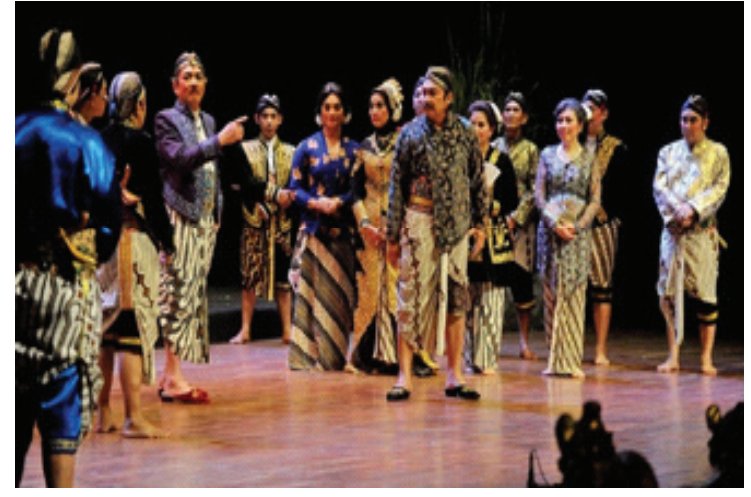

Gambar 3. Kostum Pemain Ketoprak di Jawa Tengah (Sumber:Website:http://kumpulanartikelbahasajawa.blogspot.com/2016/08/artikel-bahasajawa-kesenian-ketoprak. html)

warna, seperti merah, hijau, kuning, pink, biru, putih, dan hitam. Untuk pakaian bagian atas diberi berbagai hiasan manik-manik berwarna keemasan, jarik untuk wanita, dan juga selendang yang digunakan saat menari dengan ditambah beberapa assesoris seperti kain selempang berwarna-warni. Dari pengamatan yang dilakukan ternyata pakaian atau kostum yang dipakai pemaian tidak harus menyesuaikan dengan tokoh yang akan diperankan (lihat gambar 2).

Di Jawa, pakaian atau kostum harus menyesuaikan dengan peran karena pakaian akan mengacu pada tingkatan dan pangkat tokoh yang diperankan. Misalnya, untuk tokoh seorang prajurit keraton maka dia akan memakai seperti halnya prajurit keraton. Untuk pakaian tokoh-tokoh khusus memiliki beberapa makna simbolis, misalnya tokoh bijaksana akan memakai pakaian yang berwarna hitam, sedangkan untuk tokoh yang digambarkan orang suci maka pakaian yang dikenakan biasanya berwarna putih (Lisbijanto, 2013: 15).

Untuk pemeran pelawak dapat ditandai dari kostum yang dipakai dengan tambahan hiasan atau aksesoris lucu seperti kacamata dengan warna mencolok, bentuk sanggul yang tinggi, dan make-up yang tebal.

\section{Instrumen Musik}

Tidak ada pakem atau aturan yang tegas mengenai penggunaan alat musik pada

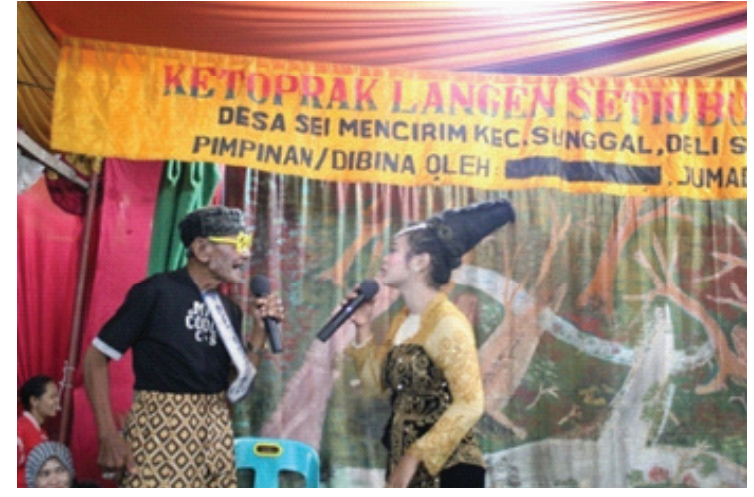

Gambar 4. Kostum dan asesoris pelawak (batur) (Foto: dokumentasi penulis, 2016)

pertunjukan ketoprak di Sumatera Utara sebagaimana di Jawa. Ketoprak di Sumatera Utara menggunakan alat musik yang berbeda dengan yang ada di Jawa. Jika di Jawa menggunakan alat musik gamelan lengkap, maka di Sumatera Utara alat musik yang dipakai lebih sederhana dan sama sekali tidak menggunakan gamelan. Alat musik tersebut ialah 1 (satu) buah keyboard atau harmonium, 2 (dua) buah kendhang, 1 (satu) buah gendang jidor dan kentrung (keprak), dan 1 (satu) set drum. (Lihat gambar 5-8, foto merupakan dokumentasi penulis, 2016).

Alat musik ini dimainkan selama pertunjukan berlangsung. Kegunaannya, selain mengiringi tembang atau lagu, juga sebagai pengiring suatu adegan, penggambaran suasana dalam cerita, memberi tekanan dramatik atas suatu peristiwa, penyekat adegan, dan juga untuk menimbulkan efek suara. Tembang atau lagu dalam pertunjukan ketoprak merupakan salah satu cara untuk menyampaikan ekspresinya. Dengan demikian, selain pandai berakting, para pemain harus mampu bernyanyi dan menari.

Lagu-lagu atau tembang dan musik yang digunakan dalam mengiringi setiap adegan atau pun selingan pergantian tokoh adalah gending sampak. ${ }^{2}$ Gending ini dimainkan pada awal, pada setiap selingan pergantian adegan dan babak pertunjukan, sedangkan musik pengiring melodis 


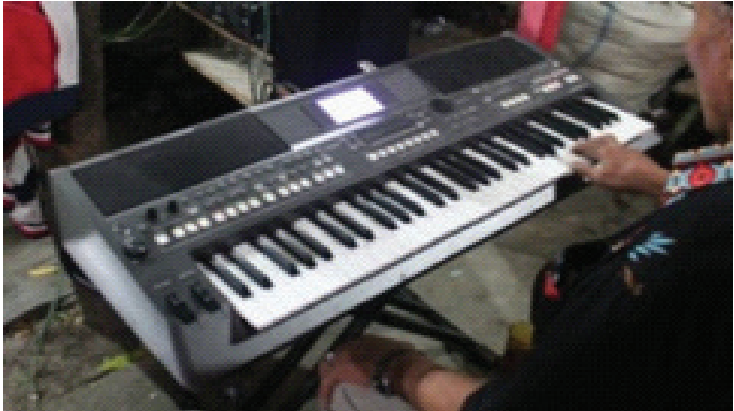

Gambar 5. Kibot (Keyboard)

(Foto: dokumentasi penulis, 2016)

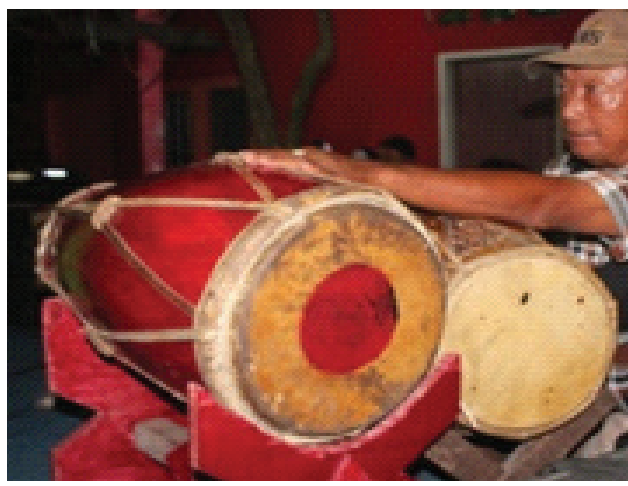

Gambar 6. Kendhang (gendang)

(Foto: dokumentasi penulis, 2016)

seperti keyboard hanya mengisi akord atau mengikuti melodi lirik lagu saja.

Pada awal pertunjukan, setelah selesai iringan gending sampak, semua pemain akan tampil ke depan panggung untuk memperkenalkan diri melalui lagu Putri Solo oleh salah seorang pemain. Penyajian lagu ini adalah untuk memperkenalkan para pemain sesuai dengan nama tokoh yang diperankannya, kemudian memperkenalkan sanggar atau grup, dan meminta izin serta maaf kepada seluruh penonton. Setelah itu, para pemain kembali ke belakang panggung dengan iringan tembang lalen mun$d u r$, artinya mengajak pemain mundur ke belakang panggung. Teks lagu Lalen Mundur adalah nyanyian berbentuk pantun yang jika diterjemahkan ke dalam bahasa Indonesia, yaitu:

Kalau ada jarum yang patah, jangan disimpan di dalam peti,

Kalau ada kata-kata yang salah, jangan di simpan di dalam hati.

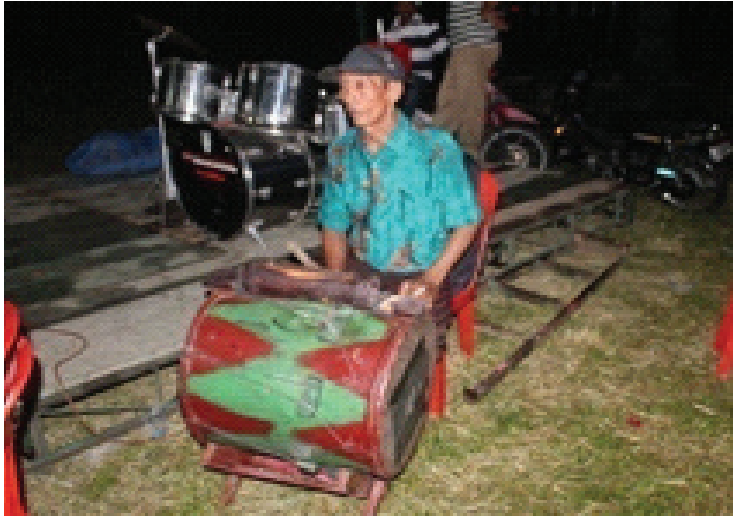

Gambar 7. Gendang Jidor dengan kentrung (keprak) menempel di atasnya

(Foto: dokumentasi penulis, 2016)

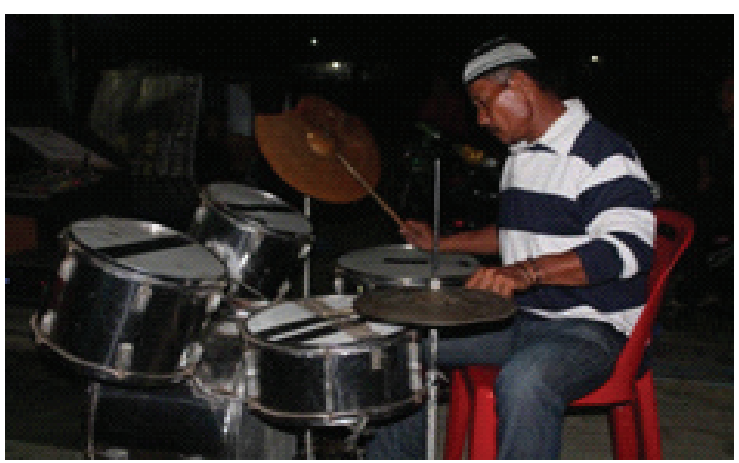

Gambar 8. Drum set

(Foto: dokumentasi penulis, 2016)

Kemudian pada bagian akhir atau penutup pertunjukan juga biasanya ada pantun yang dinyanyikan dalam bahasa Indonesia, seperti:

Kalau ada sumur di ladang, boleh kita menumpang mandi,

Kalau ada umur yang panjang, boleh kita berjumpa lagi.

Bagian awal perkenalan seperti dijelaskan di atas disebut panembromo (pembuka), yaitu awal mula sebelum memasuki babak pertama. Setelah panembromo disajikan, mulailah babak pertama dimainkan. Satu adegan biasanya tidak pernah melebihi lima babak, dan setiap pergantian babak akan ditandai dengan gending sampak sebagai pengantar dan penanda.

Kemudian pada setiap adegan gandrungan (kasmaran) lagu yang dinyanyikan adalah lagu Mijil, Adus Kulo Sari, Mina Padi, dan Tapeh Pinjong. Ketiga lagu ini mempunyai 
arti merayu seorang wanita karena kecantikan parasnya. Terkadang lagu Melayu seperti Mak Inang Pulau Kampai juga digunakan dalam adegan gandrungan.

Pada babak lawakan atau humor yang disebut goro-goro, selain dialog-dialog lucu, kadang-kadang pelawak yang berjumlah dua orang (sepasang) juga menyanyikan lagu-lagu pop Indonesia, seperti Nonton Bioskop, dan lagu-lagu plesetan yang diciptakan sendiri secara spontanitas.

Kemudian, untuk babak konflik atau perkelahian, musik pengiringya menggunakan tempo lagu cepat, seperti Patam-patam (lagu Melayu), Indung-indung (Nasyida Ria), Mbiring manggis (lagu Karo), Raja doli (lagu Batak), dan lain-lain. Terakhir, untuk babak penutup biasanya dinyanyikan lagu; Gelang Sipatu Gelang, Injit-Injit Semut, dan Kapan-kapan (lagu non-Jawa).

\section{Waktu Pertunjukan}

Pertunjukan ketoprak lazimnya dilaksanakan pada malam hari pukul 21.00 sampai dengan pukul 04.00 WIB atau lebih. Pertunjukan tidak pernah dilakukan pada siang hari, karena dapat mengurangi estetika, rasa percaya diri pemain, dan suasana pertunjukan. Malam hari adalah waktu yang tepat karena pemain dapat merasakan atau menghayati peran tokoh yang dibawakannya melalui lampu-lampu atau efek dari kostum yang dipakai. Selain itu, karena pada malam harilah waktu luang bagi pemain ketoprak dan masyarakat untuk menyaksikannya.

\section{Manajemen Ketoprak}

Kelompok ketoprak memiliki sistem manajemen tradisional. Menurut Takari (2008: 64-73) manajemen tradisional memiliki ciri-ciri ketika gagasan, kegiatan, atau benda-benda yang diturunkan dari satu generasi ke generasi mengikuti norma-norma yang terjadi di lingkungan masyarakat itu sendiri, antara lain:

1) Berkesenian sebagai kerja samping- an atau sambilan. Para pemain ketoprak di Sumatera Utara umumnya hanya sekadar meneruskan tradisi yang telah ada dengan istilah melestarikan atau mengembangkannya. Berkesenian hanyalah sebagai pekerjaan sambilan, dengan manajemen "sambilan" pula. Waktu yang diluangkan untuk kegiatan berkesenian juga adalah waktu sambilan, di luar kerja utama profesi seseorang seniman.

2) Menonjolkan pimpinan yang biasanya juga sebagai seniman utama dan penyandang dana utama organisasinya. Pimpinan ketoprak adalah juga merangkap posisi ganda sebagai seniman utama, sutradara, dan penyandang dana organisasi. Pimpinan dengan manajerial yang kuat dan tidak mewariskannya pada generasi selanjutnya, maka kelompok kesenian yang dipimpinnya akan mati. Kalau penerusnya mengikuti pola yang sama tetapi dengan kapasistas yang kurang mumpuni, maka akan terjadi degradasi sosial dalam kelompok kesenian ini.

3) Pembagian honorarium yang agak bersifat rahasia, dan biasanya dicarikan kata-kata yang "manis" seperti "uang pupur", "uang lelah," dan sejenisnya. Ciri manajemen seni secara tradisional adalah pembagian hasil jerih payah secara bersama, kurang menghargai peran integral keseluruhan pelaku seni (seniman, kru, dan pihak pimpinan). Biasanya, honorarium ditentukan oleh pimpinan saja. Agar uang hasil kerja bersama ini dapat diambil sebesar-besarnya oleh pimpinan kesenian, maka istilah yang digunakan cenderung menggunakan kata-kata yang bermosi kerja sebagai kerja sampingan, seperti "uang pupur" (uang bedak), "uang lelah", "uang rokok", "uang terima kasih", uang transport, dan sejenisnya.

4) Pembagian tugas tidak begitu spesifik. Ciri lain manajemen seni tradisional ketoprak adalah tugas yang tumpang tindih. Jarang seorang pemain hanya mengerjakan 
satu pekerjaan. Kadang sebagai seniman, ia juga harus mengangkat alat musik, tata lampu, properti tari, dan juga merangkap sebagai pemeran dan pemusik. Pembagian kerja yang tidak spesifik ini biasanya akan mengurangi tanggung jawab dan tugas khususnya. Pendekatan semacam ini, berdasar kepada asumsi bahwa mereka adalah keluarga besar, oleh sebab itu tanggung jawab dipikul secara bersama-sama layaknya keluarga. Kerja pun harus dikerjakan bersama-sama dalam sistem gotong royong, dan seterusnya. Cara kerja seperti ini, biasanya para seniman muda dan yang berjenis kelamin laki-laki diutamakan untuk bekerja ekstra keras, dengan alasan tenaganya masih kuat, masih muda, dan masih jauh masanya berkarir di bidang seni.

5) Organisasi kesenian tradisional jarang dibentuk secara yuridis. Sebuah organisasi kesenian biasanya dibentuk hanya berdasarkan musyawarah mufakat untuk kelestarian budaya semata. Sebagian besar kelompok ketoprak di Sumatera Utara tidak memiliki kekuatan hukum dalam pendiriannya. Biasanya pimpinan ketoprak hanya mencantumkan nama dan alamat di papan nama atau pun spanduk pertunjukan.

6) Perekrutan seniman sifatnya "cabutan". "Cabutan" adalah seniman dari kelompok lain bergabung untuk memenuhi permintaan pertunjukan. Alasan melakukan ini adalah banyak seniman ingin menambah penghasilan keuangannya melalui banyaknya pertunjukan. Ia tak mau terikat hanya dalam satu organisasi kesenian saja, karena jarang sekali ada sebuah organisasi kesenian yang membayar gaji seniman secara rutin setiap bulan dengan jumlah tertentu sebagaimana layaknya tenaga kerja. Berdasarkan pengamatan yang dilakukan, hampir seluruh pemain ketoprak saling mengenal satu sama lainnya karena berlatar belakang yang sama, yaitu buruh Jawa. Namun, oleh karena tempat domisili para pemain yang sudah terpisah-pisah, maka sering terjadi pemain "cabutan". Kelom- pok ketoprak di Sumatera Utara kebanyakan pemain-pemainnya adalah orang yang sama meskipun kadang-kadang pada setiap pertunjukannya mendapatkan peran yang berbeda.

7) Asas keluarga dan kekeluargaan. Sistem manajemen ini banyak diterapkan oleh organisasi-organisasi kesenian di Nusantara. Sistem ini memang memiliki kelebihan di satu pihak, yaitu para anggotanya merasa sebagai satu keluarga besar, yang terikat hubungan kekerabatan dan darah, sehingga masalah yang timbul dengan mudah dapat dipecahkan berasaskan kekeluargaan. Di sisi lain, sistem ini kurang demokratis, artinya bakat-bakat seniman yang handal di luar keluarga, agak sulit untuk masuk ke dalam organisasi seni tersebut. Kualitas sumber daya manusia dan produksi seni dalam organisasi seperti ini hanya menjadi nomor sekian saja. Selain itu, pengembangan yang ekstensif kurang diperhatikan. Misalkan saja sejak zaman dahulu, mereka mewarisi kesenian ketoprak, maka sampai sekarang pun mereka akan memproduksi kesenian yang sama. Untuk membuka diri memproduksi seni rakyat atau etnik lain agak kurang, karena pembatasan sumber daya manusia seni tadi.

8) Sangat erat dengan ritual masyarakat. Setiap seniman ketoprak tidak mengharapkan uang lelah atau uang honorarium. Mereka tidak keberatan jika hanya diberi amplop yang berisi uang Rp 50.000 setiap orangnya atau hanya sekadar membeli sebungkus rokok saja. Sekali lagi uang atau honor berkesenian bukan yang utama di sini, yang berperan adalah konsep-konsep dan aktivitas religius, yang memotivasi setiap orang dan seniman untuk melakukannya menurut fungsi individunya dalam konteks masyarakat luas dengan cita-cita dan tujuan bersama.

\section{Pengembangan dan Keberlanjutan Ketoprak}

Kelompok-kelompok seni pertunjukan tradisional Ketoprak di Sumatera Utara 
telah mengalami pasang surut sejak awal keberadaannya hingga saat ini, yang diakibatkan oleh perkembangan zaman, kemajuan teknologi, kompleksitas kebutuhan, dan selera masyarakat yang terus berubah. Beberapa kelompok ketoprak di Sumatera Utara yang masih bertahan hingga sekarang, ialah 1) Langen Mardi Agawe Rukun Santosa (LMARS), 2) Langen Setio Budi Lestari (LSBS), 3) Langen Mudo Siswo Budoyo (LMSB), 4) Langen Sri Wulandari (LSW), 5) Langen Wahyu Tri Budoyo (LWTB), 6) Langen Pujakesuma (LP), 7) Langen Buluh Cina (LBC), 8) Langen Madyo Tresno (LMT), dan 9) Langen Madyo Utama (LMU).

\section{Strategi Pengembangan Seni Pertunjukan Tradisional Ketoprak di Sumatera Utara}

Berkembangnya seni dan budaya dapat dipengaruhi oleh faktor internal dan eksternal, yaitu kreativitas manusia yang tumbuh dari dalam dirinya yang melahirkan ide-ide baru yang original, dan faktor lingkungan hidup yang meliputi lingkungan alam dan lingkungan sosial budaya.

Mengembangkan kesenian daerah seperti ketoprak adalah menghidupkan zaman yang sedang tumbuh, bergerak, hidup, lentur, dan berkarakter secara terintegratif. Kesenian daerah adalah investasi masa depan bagi seluruh hajat hidup dan kemaslahatan umat manusia. Untuk itu perlu digali, dieksplorasi, dan diterjemahkan dalam ruang dan waktu zamannya. Seni-seni daerah bukanlah barang mati yang tidak bisa bersentuhan dengan zamannya. Seketat apapun seni-seni daerah dalam menjaga keasliannya, proses inovasi tetap terbuka. Demikian juga, ketoprak perlu penyegaran warna, bentuk, pola ucap, kesan, hingga komunikasinya dengan masyarakat yang baru, dengan kebudayaan yang baru, dan dengan manusia-manusia baru yang memiliki berbagai latar belakang yang berbeda-beda, baik asal-usul, etnis, bahasa, pendidikan, maupun pekerjaan agar dapat tersambung.
Upaya mengembangkan seni daerah bukan tidak memiliki tantangan yang besar. Tantangan dari birokrasi pemerintah, perubahan sosial, maupun keagamaan hingga dunia pendidikan yang tidak kondusif. Birokrasi pemerintah terkadang kurang melakukan pendekatan yang dapat merangsang pekembangan kesenian daerah, karena objek operasional birokrasi pemerintah lebih kepada pencapaian pendapatan asli daerah (PAD) melalui usaha-usaha yang prosesnya relatif cepat. Dengan kata lain, seni-seni daerah belum menjadi bagian investasi bagi pembangunan daerah.

Umar Kayam (1981) mengakui bahwa seni-seni tradisional atau seni-seni daerah sulit memasuki wilayah modern, dan sulit melakukan proses integrasi-nasional karena posisinya yang bertolak belakang. Untuk itu, kelompok-kelompok seni, sosial, atau pun keagamaan harus bersatu menghadapi kekuatan yang merongrong instabilitas dalam kehidupan berkesenian itu sendiri. Sedangkan dunia pendidikan dapat menjadi media yang mampu melakukan kajian-kajian terhadap kemungkinan terbukanya proses berkesenian bagi seluruh pelaku seni daerah.

Di samping itu, mindset dan starting point dalam membangun kesenian saat ini semakin kabur karena ambiguitas zaman maupun kebijakan-kebijakan yang dibuat dalam memahami seni daerah. Hal ini semakin mengaburkan output dan input pengembangan seni daerah. Untuk itu, paling sedikit terdapat tiga pola untuk pengembangan kesenian secara gradual. Ketiga pola itu adalah seni daerah yang mampu didukung oleh pemerintah, komunitas, dan dunia komersial.

Ketiga pola di atas belum menjadi titik tolak dalam pengembangan seni daerah karena belum terdapat pola kebijakan yang bersifat holistik dari masing-masing daerah atau lembaga-lembaga yang memiliki kewenangan dalam pengembangan seni daerah. Masing-masing lembaga masih bekerja untuk dirinya sendiri dan belum 
memosisikan diri secara terintegratif sesuai kebutuhan masyarakat (Abdillah, 2011).

1. Dikemas dalam Pertunjukan Pariwisata Ketoprak dapat ditampilkan di tempat hiburan umum dan pariwisata, sehingga lambat laun semakin dikenal secara luas untuk kemudian dapat diterima oleh masyarakat dengan baik sebagai produk wisata. Untuk itu, waktu pementasannya perlu dipadatkan dan dipersingkat. Pertunjukan ketoprak harus komunikatif, artinya pesan-pesan dalam dialog-dialognya harus dapat dicerna dan dipahami oleh penonton. Penggunaan bahasa Jawa perlu dipertimbangkan untuk menggunakan bahasa yang umum dipahami oleh penonton, tanpa menghilangkan identitas dan jati dirinya sebagai kesenian tradisional ketoprak. Dengan perkataan lain, seni pertunjukan tradisional Ketoprak perlu penyegaran keanggotaan, waktu, teknologi, warna, bentuk, pola, kesan hingga komunikasinya dengan masyarakat yang baru, dengan kebudayaan yang baru, dan tentu dengan manusia-manusia baru yang memiliki berbagai latar belakang pendidikan dan pekerjaan agar dapat tersambung. Hal ini sesuai dengan pernyataan Fitriani (2012: 80) bahwa industri kreatif adalah industri yang mengandalkan kreativitas, keahlian, dan bakat individu yang berpotensi untuk menghasilkan kekayaan dan menciptakan lapangan kerja dengan mengoptimalkan potensi itelektual yang dimiliki.

Melalui pertunjukan di tempat pariwisata maka masyarakat akan lebih sering melihat pementasan ketoprak sebagai produk wisata, di sisi lain seniman akan memperoleh uang. Kusumastuty (2009: 10) mengatakan bahwa dalam pengembangan kesenian diperlukan seniman yang konstruktif yang mampu menjawab tuntutan dan tantangan zaman serta dapat memadukan antara kepentingan pariwisata dan kesenian sebagai cita-cita spiritual. Hal ini sangat penting supaya seniman tidak terjebak pada trend wisata dan cenderung cepat berubah mengikuti selera pasar dengan menghilangkan orisinalitas dan keunikannya. Untuk itulah dalam pengembangan kesenian ketoprak menjadi industri kreatif tidak boleh meninggalkan pakemnya.

2. Disebarluaskan Melalui Media Sosial, Elektronik, dan Cetak

Pementasan ketoprak oleh stasiun televisi adalah salah satu upaya pengembangan kesenian ketoprak kepada masyarakat luas. Demikian pula penyebaran informasi melalui media cetak serta media sosial seperti Facebook, WhatsApp, LINE, SMS, $H P$, telepon, dan media lainnya, sangat membantu dalam penyebaran informasi ketoprak kepada masyarakat luas. Dirjen Informasi dan Komunikasi Publik (2011: 93) mengatakan bahwa media massa, baik cetak maupun elektronik perlu dilibatkan untuk penyebarluasan nilai-nilai universal kesenian ke masyarakat luas. Dengan demikian, ketoprak dapat diketahui oleh masyarakat luas untuk kemudian datang menyaksikan pertunjukannya.

3. Bernaung pada Institusi Nonformal

Strategi pengembangan kesenian ketoprak menjadi industri hiburan, salah satunya adalah bernaung pada yang disebut langen (sanggar) dan Jede (Komunitas Jawa Deli). Dengan naungan ini, ketoprak dengan cepat dapat disebarkan kepada masyarakat luas. Hal ini selaras dengan anjuran Departemen Perdagangan RI (2008: 53) bahwa pengembangan industri kreatif harus didukung oleh pilar utama, yaitu sebuah institusi. Peranan institusi sangat penting, sebab industri kreatif memajukan ide-ide yang dieksploitasi menjadi potensi ekonomi. Untuk itulah diperlukan institusi yang memiliki tatanan sosial berisi kebiasaan, norma, adat, dan aturan yang bersifat nonformal.

Pada tahun 1970-an di masa kejayaannya, ketoprak di Sumatera Utara dibina oleh Badan Koordinasi Kesenian Jawa (BKKJ) Sumatera Utara yang dipimpin oleh Soekardi. Pada masa itu, para seniman mendapat support yang baik, di samping 
antusiasme masyarakat yang tinggi kepada para pemain. Suriat (67) masih ingat betul, di era 1960-1970-an, saat masa keemasan ketoprak, sehari ia bisa bermain pada empat tempat berbeda. Penampilan bapak delapan anak ini, dulu memang selalu ditunggutunggu penggemarnya. Para perempuan akan merubung atau mengajak mampir ke rumahnya, tak sedikit yang mengajak kawin. Ia bahkan sempat ditawari jadi polisi asal mau kawin dengan gadis yang memiliki relasi si pemberi janji. Lain lagi dengan Jumadi (65), tak hanya dirubung perempuan, gaya rambut 'jambul-colok'nya juga banyak ditiru penggemarnya. Suriyat dan Jumadi adalah dua dari sekian bintang panggung ketoprak yang masih tersisa sampai kini. Banyak pemain seangkatannya sudah meninggal dunia. Sebagian memilih berhenti bermain. Alasanya beragam, selain faktor usia, kesibukan mencari penghidupan, juga trauma dengan peristiwa kekerasan politik 1965. Menurut Suriyat, banyak anggota grup yang trauma, lalu tak mau main ketoprak lagi. Terutama kelompok ketoprak yang dianggap 'tidak bersih' oleh aparat keamanan."Tahun 1970-an, sebelum main, kita ditanya aparat keamanan, lakonnya apa? Kita tak boleh mengkritik pemerintah," ujar Suriyat (Analisa, 13 Agustus 2017). Namun, seiring dengan perjalanan waktu, kesenian ini kemudian semakin ditinggalkan oleh masyarakat karena tergerus oleh kemajuan zaman dan perkembangan teknologi.

4. Kerja Sama dengan Masyarakat, Komunitas, dan Pemerintah

Kerja sama dengan masyarakat, teman antar-paguyuban di berbagai langen, misalnya antara LMARS Medan Deli dan LSBL Deli Serdang atau dengan LSMB di Binjai-Stabat dilakukan oleh para pemain kesenian ketoprak Sumatera Utara. Selain itu, para pemain juga melakukan kerja sama dengan pemerintah, khususnya Kementerian Pendidikan dan Kebudayaan, dengan komunitas tertentu seperti Komu- nitas Jawa Deli (Jede), Pandawa, dan Pujakesuma. Melalui kerja sama ini kesenian ketoprak diharapkan mendapat undangan dari masyarakat dan pemerintah untuk mengadakan pementasan. Temuan penelitian tersebut selaras dengan pernyataan Departemen Perdagangan RI (2008: 54) bahwa pengembangan industri kreatif harus didukung oleh aktor utama, yaitu seniman, bisnis, dan pemerintah. Dalam hal ini, pengembangan ketoprak menjadi industri kreatif sudah didukung oleh seniman ketoprak, bisnis dari masyarakat, teman antar paguyuban, dan pemerintah.

\section{Pementasan Secara Rutin}

Sebelum ketoprak dipentaskan sebaiknya dilakukan latihan rutin untuk menyegarkan ingatan, menambah kreativitas para pemainnya untuk menghasilkan inovasi-inovasi dalam menyiasati era globalisasi. Latihan yang rutin akan meningkatkan kepercayaan para pemain untuk memaksimalkan setiap perannya. Hasil latihan tersebut kemudian dipentaskan secara rutin pada hari tertentu seperti HUT Kemerdekaan RI, sunatan, pesta pernikahan, suroan, dan lain-lain. Hal ini sangat penting supaya masyarakat mulai terbiasa dan mulai tertarik kembali untuk menyaksikan pementasan ketoprak.

Berdasarkan pengamatan penulis, perwatakan dan karakter para tokoh dalam pertunjukan ketoprak sering kali tidak konsisten, bahkan cenderung lemah. Suheri (55) mengatakan, para pemain ketoprak kurang memahami teknik pertunjukan teater modern. Dengan pemahaman yang minim tersebut, watak dan karakter tokoh yang diperankan belum meresap ke dalam diri pemain. Akibatnya, karakter tersebut menjadi lemah dan kurang menyentuh.

\section{Kendala dalam Pengembangan Seni Per- tunjukan Tradisional Ketoprak di Suma- tera Utara}

Beberapa kendala dalam Pengembangan seni pertunjukan tradisional Ketoprak di 
Sumatera Utara, antara lain; disiplin, faktor usia, sepinya permintaan, minimnya properti pertunjukan.

1. Disiplin

Disiplin dalam bekerja dan berkarya adalah salah satu kunci dari kesuksesan. Ketidakdisiplinan untuk latihan, mengembangkan watak, karakter, dan kemampuan para pemain adalah salah satu kendala dalam pengembangan seni pertunjukan tradisional Ketoprak di Sumatera Utara. Ketidakdisiplinan ini menyebabkan pertunjukan kurang mendapat 'greget' di samping pemahaman ilmu teater yang sangat minim. Para pemain hanya mengandalkan pengalaman masa lalu tanpa berusaha menyesuaikan dengan masa kini dan berinovasi untuk masa depan.

Dengan keadaan tersebut, ketoprak hanyalah sisa dari puing-puing kejayaan masa lalu yang sudah tidak menarik lagi untuk ditonton terutama oleh generasi muda. Ketoprak LMARS, LSBL, LMSB, misalnya hanya melakukan pertunjukan sekali dalam sebulan. Dengan demikian, produksinya dapat dikatakan sangat rendah. Hal ini menjadi kendala yang sangat umum dalam mewujudkan ketoprak sebagai industri kreatif karena seniman sebagai tenaga kerja mendapatkan upah pada saat ada pertunjukan saja.

\section{Faktor Usia}

Para pemain ketoprak mayoritas berusia di atas 50 tahun, padahal dalam pementasannya diperlukan orang-orang muda untuk memerankan tokoh yang muda pula. Pada cerita tertentu para pemain tua harus memerankan tokoh yang masih muda. Menurut peneliti, para pemain tua ini adalah salah satu penyebab pementasan ketoprak kurang menarik, kurang menantang, dan kurang inovatif. Tokoh putri raja nan cantik jelita yang bernama Sriwati misalnya, harus diperankan oleh tokoh A yang berusia di atas 50 tahun, menjadikan peran ini kurang sesuai dan maksimal walaupun di-make up sedemikian rupa.

\section{Sepinya Permintaan}

Permintaan pementasan ketoprak oleh anggota masyarakat hanya terbatas pada orang-orang tertentu saja. Suriat (pimpinan LMARS) dan Wakijan (Pimpinan LMSB) mengatakan banyak permintaan ketoprak yang batal karena anak-anak dari keluarga pengundang lebih memilih bentuk hiburan modern lain (seperti Kibot (keyborad -ed.), Band, dan lain-lain). Oleh karena itu, keberadaan kesenian ini sudah cukup memprihatinkan. Ketoprak tidak bisa diharapkan menjadi tontonan yang menarik dan menjadi sumber penghasilan bagi pemainnya.

\section{Properti yang Minim}

Properti pendukung pertunjukan juga menjadi salah satu faktor penyebab pertunjukan ini kurang menggambarkan suasana lakon. Singgasana kerajaan misalnya hanya terbuat dari kursi plastik saja. Begitu pula busana raja dan permaisuri juga tidak jauh berbeda dengan busana pemain lainnya. Properti pendukung seyogianya haruslah mendekati keadaan yang sebenarnya supaya apa yang digambarkan dapat terwakili baik secara audio maupun visual.

5. Belum Adanya Perusahaan atau Organisasi yang Memasarkan dan Menyebarluaskan Secara Rutin

Pengembangan ketoprak belum dapat dipasarkan secara luas. Hal ini dikarenakan belum adanya perusahaan dalam bidang hiburan, seperti perusahaan rekaman, stasiun televisi yang berminat memasarkannya. Kesenian ini hanya beberapa kali saja tampil di beberapa stasiun televisi, sehingga belum dapat menghasilkan profit yang besar. Dana untuk pengembangan ketoprak hanya berasal dari hasil undangan anggota masyarakat saja. Temuan penelitian tersebut selaras dengan pernyataan Departemen Perdagangan RI (2008: 54) bahwa aktor utama pengembangan industri kreatif harus didukung oleh aktor bisnis. Aktor bisnis ini meliputi pelaku usaha, investor dan konsumen industri kreatif. Peran aktor bisnis 
adalah menciptakan variasi baru berupa produk dan jasa supaya lebih menarik dan dapat menghasilkan profit serta meningkatkan kemakmuran para pemiliknya.

6. Belum Ada Lembaga Keuangan yang Mampu Memberi Pinjaman untuk Mendukung Pementasan Ketoprak

Pementasan ketoprak belum dapat dikomersialkan secara baik karena belum adanya orang dan lembaga yang mampu meminjami dan mengelola keuangan dalam pementasannya. Sampai saat ini, dana yang digunakan dalam pementasan ketoprak adalah dana dari hasil tanggapan masyarakat, pemerintah, atau pun dari anggota kelompok itu sendiri. Diperlukan peran lembaga penyalur keuangan untuk mendukung pengembangan kesenian ketoprak menjadi industri kreatif. Hal ini sesuai dengan pernyataan Departemen Perdagang-an RI (2008: 53) bahwa untuk mendukung pengembangan industri kreatif harus didukung oleh pilar lembaga penyalur keuangan. Lembaga penyalur keuangan berperan sebagai penyalur pendanaan kepada pelaku industri yang membutuhkan pendanaan kepada pelaku industri, baik dalam bentuk modal maupun pinjaman.

\section{Upaya Mengatasi Kendala dalam Pengem- bangan Seni Pertunjukan Tradisional Ke- toprak di Sumatera Utara}

Berdasarkan deskripsi dan analisis data yang diperoleh melalui wawancara, observasi, dan dokumentasi maka diperlukan upaya dalam mengatasi kendala pengembangan kesenian ketoprak sebagai berikut:

1. Mengadakan Pertemuan Rutin antara Kelompok Ketoprak dan Masyarakat

Minimal setiap enam bulan sekali paguyuban ketoprak perlu mengadakan perkumpulan untuk membahas perkembangan kesenian ini. Pada acara ini dihadiri oleh perangkat desa, masyarakat sekitar, dan pengurus serta anggota sanggar. Tujuan utama pertemuan ini adalah supaya diperoleh informasi, saran, dan masukan untuk pengembangan kesenian ini.
2. Memaksimalkan Peran Sanggar bagi Pemula untuk Mendapatkan Pemain Ketoprak

Sanggar (langen) adalah pusat latihan dan tempat pengembangan ide, gagasan, dan kreativitas para pemain ketoprak. Bagi para pemula, latihan sangat membantu dalam memperoleh pemain yang baru. Adanya sanggar mempunyai tujuan supaya anak muda lebih tertarik belajar. Para pemain yang mampu mendayagunakan ide, talenta, dan kreativitasnya akan sangat mendukung dalam pengembangan kesenian ini menjadi industri kreatif. Kusumastuty (2009: 10) mengatakan bahwa pengembangan kesenian memberikan dampak positif dalam rangka pelestarian dan pengembangannya.

Untuk itulah diperlukan regenerasi dalam pelestarian ketoprak. Melalui sanggarsanggar akan didapatkan pemain-pemain baru sebagai generasi penerus pengembangan kesenian ini di Sumatera Utara.

3. Bekerja Sama dengan Pemerintah, Masyarakat, dan Teman Sesama Anggota

Dana yang diperoleh dari kerja sama dengan masyarakat, teman antarsanggar, dan pemerintah digunakan untuk kepentingan pementasan ketoprak dan kepentingan para pemainnya, seperti membeli kostum, tata rias, perbaikan peralatan musik, dan panggung. Kepentingan para pemain ialah berupa honorarium atas karya dan pekerjaan yang telah dilakukannya. Temuan penelitian tersebut selaras dengan pendapat Mulyono (1978: 272) bahwa pembangunan kesenian seperti halnya ketoprak tidak boleh grusa-grusu (gegabah) sebab di samping pembaharuan memerlukan waktu, kesabaran, ketelitian, kematangan rasa dan pikiran, juga memerlukan pengetahuan yang luas serta dana yang cukup.

\section{SIMPULAN}

Sejak ketoprak dibawa dari Jawa Tengah ke Sumatera Utara pada tahun 1920an, seni pertunjukan ini telah mengalami 
pasang surut dalam perjalanannya. Masa kejayaan ketoprak pada tahun 1960-1970an menempatkan kesenian ini menjadi primadona dalam dunia hiburan di Sumatera Utara masa itu. Para pemainnya menjadi bintang dan idola dengan kuantitas pertunjukan yang tinggi dan pendapatan yang tinggi pula. Sebagai kesenian yang hidup dan berkembang khususnya di tanah Deli, ketoprak juga mengadopsi budaya setempat untuk menyesuaikan dengan selera penonton dan masyarakat sekitarnya. $\mathrm{Na}-$ mun, seiring dengan perkembangan zaman dan hadirnya berbagai media hiburan yang baru, terutama pengaruh teknologi informasi yang mampu menjangkau sendi-sendi kehidupan masyarakat, akhirnya ketoprak mulai ditinggalkan oleh penggemarnya. Banyak grup ketoprak yang gulung tikar, dan para artisnya beralih profesi demi mempertahankan hidup. Bentuk dan kualitas pertunjukan yang semakin tidak menarik dan tidak up to date menjadi salah satu penyebab kesenian ini ditinggalkan. Jika ketoprak masih ingin dipertahankan, para penggiat seni pertunjukan ini dituntut mampu mengembangkan diri sesuai dengan selera dan kebutuhan masyarakat.

Oleh karena aspek cerita dalam pertunjukan ketoprak sebagai kesenian rakyat bukanlah pakem yang kaku, maka diperlukan inovasi-inovasi baru agar dapat bertahan dan tetap digemari masyarakat dan penontonnya. Hal ini dilakukan agar ketoprak bangkit dan berjaya lagi menjadi salah satu seni tontonan yang berisi tuntunan di tengah-tengah himpitan teknologi dan perkembangan zaman saat ini.

\section{Catatan Akhir:}

${ }^{1}$ Ada dua pendapat mengenai sejarah asalusul ketoprak. Menurut Kayam (2000: 342), ketoprak berasal dari Klaten, Jawa Tengah. Penciptanya tidak diketahui secara pasti, namun menurut Lisbijanto (2013: 1), ketoprak diciptakan oleh R.M. Wreksodiningrat dari Surakarta pada tahun 1914.

${ }^{2}$ Gending sampak dimainkan secara berulang-ulang pada setiap pergantian babak baru pada pertunjukan ketoprak. Setiap pemain yang sudah selesai memerankan adegannya akan kembali ke belakang panggung diiringi gending sampak, dan untuk masuk ke babak selanjutnya juga akan diiringi gending sampak, begitu seterusnya sampai babak penutup.

\section{Daftar Pustaka}

Abdillah, A. (2011). Upaya Pengembanan Kesenian Tradisional dan Tantangannya. Makalah Workshop Kesenian Daerah, pada tanggal, 22 November 2011 di Dewan Kesenian Kabupaten Sampang, Madura.

Dewi, H. (2016). “Keberlanjutan dan Perubahan Seni Pertunjukan Kuda Kepang di Sei Bamban, Serdang Bedagai, Sumatera Utara" dalam Panggung 26 (2), 139-150.

Hariadi, S. (2015). Studi Deskriptif Ketoprak Dor Pada Upacara Adat Perkawinan Jawa di Kelurahan Jati Makmur, Kecamatan Binjai Utara, Kota Binjai. Skripsi S-1 Etnomusikologi, FIB USU.

Kartodirdjo, S. (1982). Pemikiran dan Perkembangan Historiografi Indonesia, Suatu Alternatif. Jakarta: PT Gramedia.

Kayam, U. (1981). Seni, Tradisi, Masyarakat. Jakarta: Sinar Harapan.

Lisbijanto, H. (2013). Ketoprak. Yogyakarta: Graha Ilmu.

Merriam, A. P. (1964). The Anthropology of Music. Evastol Ill: Northwestern University Press.

Murgianto, S. (2003). Mencermati Seni Pertunjukan Dalam Persfekstif Kebudayaan, Ritual, Hukum. Jakarta: The Ford Foundation.

Naiborhu, T. \& Karina, N. (2016). Model Pengembangan Kesenian Tradisional Ketoprak di Sumatera Utara. Laporan Akhir Penelitian DRPM Kemenristekdikti, USU Medan. - (2017). Pengembangan dan Keberlanjutan Seni Pertunjukan Tradisional Ketoprak di Sumatera Utara. Laporan Akhir Penelitian Talenta Universitas Sumatera Utara. Medan: USU Medan. 
Reid, A. (1987). Perjuangan Rakyat dan Revolusi Hancurnya Kerajaan di Sumatera. Jakarta: Sinar Harapan.

Said, M. (1990). Koeli Kontrak Tempo Doeloe: Dengan Derita dan Kemarahannya. Medan: PT. Harian Waspada.

Subanar, B. (2006). Sebuah Geliat dalam Dunia Ketoprak Jaman Ini Makna Simbol dan Fungsi Seni Pertunjukan di Tengah Perubahan Jaman. Makalah disajikan pada Diskusi Sejarah Seni Pertunjukan yang diselenggarakan oleh Balai KaKajian Sejarah dan Nilai Tradisional Yogyakarta, Kalasan 17-18 Mei 2006.
Sugiarti, T. (1989). Ketoprak Dor: Perkembangan, Fungsi dan Tantangannya Di Sumatera Utara (1920-1985). Skripsi S-1 Sejarah FIB USU Medan.

Suroso, P. (2012). Ketoprak Dor di Helvetia. Medan: CV Budi Utomo.

Takari, M. (2008). Manajemen Seni dalam Jurnal Studia Kultura 13 (7), 64-73.

Van Langenberg, M. (1976). National Revolution in North Sumatra: Sumatra Timur and Tapanuli 1942-1950. PhD thesis. University of Sydney. 